\title{
BLOOM OF ALEXANDRIUM FRATERCULUS IN COASTAL WATERS OFF ITAJAÍ, SC, SOUTHERN BRAZIL
}

Claudia Yuki Omachi*, Márcio da Silva Tamanaha \& Luís Antônio de Oliveira Proença

Universidade do Vale do Itajaí

Centro de Ciências Tecnológicas da Terra e do Mar

Laboratório de Estudos sobre Algas Nocivas

(Rua Uruguai, 458, Bloco 19, 88302-202 Itajaí, SC, BRAZIL)

*corresponding author: comachi@gmail.com

Descriptors: Alexandrium, dinoflagellates, bloom, red tide, phycotoxin.

Descritores:

Alexandrium fraterculus (Balech) is a marine dinoflagellate found in warm waters worldwide with its occurrence in the Southwestern Atlantic associated to the Brazilian Current (Balech, 1995). Although no bloom concentrations had been observed until 1995 (Fukuyo et al., 1990; Balech, 1995) it became a phenomenon often observed in New Zealand since 1998 with concentrations frequently higher than an order of $10^{3}$ cells $\mathrm{L}^{-1}$ (MacKenzie et al., 2004). In Santa Catarina (SC), a southern Brazilian state, this phytoplankter has been commonly found in coastal waters in low concentrations (Rörig et al., 1998; Proença et al., 2002). Here we report a bloom of $A$. fraterculus in coastal waters off SC detected in 2004, the first record of this kind in Brazil.

Patches of discoloured water were spotted from the shore in the Cabeçudas beach, Itajaí, SC, on August $19^{\text {th }} 2004$ and they were sampled in the adjacent beach of Atalaia the day after. These beaches are adjacent to the Itajaí-açu estuary (Fig. 1). Ten days later, discoloured water was spotted again and sampled in the Cabeçudas beach.

Another set of samples from the weekly monitoring programme (WMP), collected between August $12^{\text {th }}$ and September $16^{\text {th }} 2004$ was also analysed to compare with samples from the blooms. This WMP is run by the UNIVALI for identification of potentially toxic phytoplankton and phycotoxins in Armação do Itapocoroy, Penha, SC (Rörig et al., 1998; Proença et al., 1998b) which is about $20 \mathrm{~km}$ distant in a straight line from the two bloom sites (Fig. 1).

Samples collected in the blooms were dominated by $A$. fraterculus in chains with up to 60 cells, which were broken in the Lugol's fixation by the time of counting, one month later. The identification of the species was carried out in the cultured samples. Chains of $A$. fraterculus from both bloom samples were isolated with capillary tubes and incubated in a nutrient enriched seawater medium $\mathrm{f} / 2, \quad 12: 12$ day:night cycle at $20^{\circ} \mathrm{C}$ and salinity around 33 to 34 .
A. fraterculus grew well in the culture forming long chains with up to 56 cells (Figs 2a; 2b). The morphology of the main thecal plates (Balech, 1995; MacKenzie et al., 2004) was analysed using a phase contrast Olympus IX50 and a UV epifluorescence Olympus BX40 microscopes on the Calco Fluor stained samples. A. fraterculus was identified by examining the apical pore complex, first apical plate and posterior sulcal plate (Balech, 1995; MacKenzie et al., 2004) (Figs 2c; 2d).

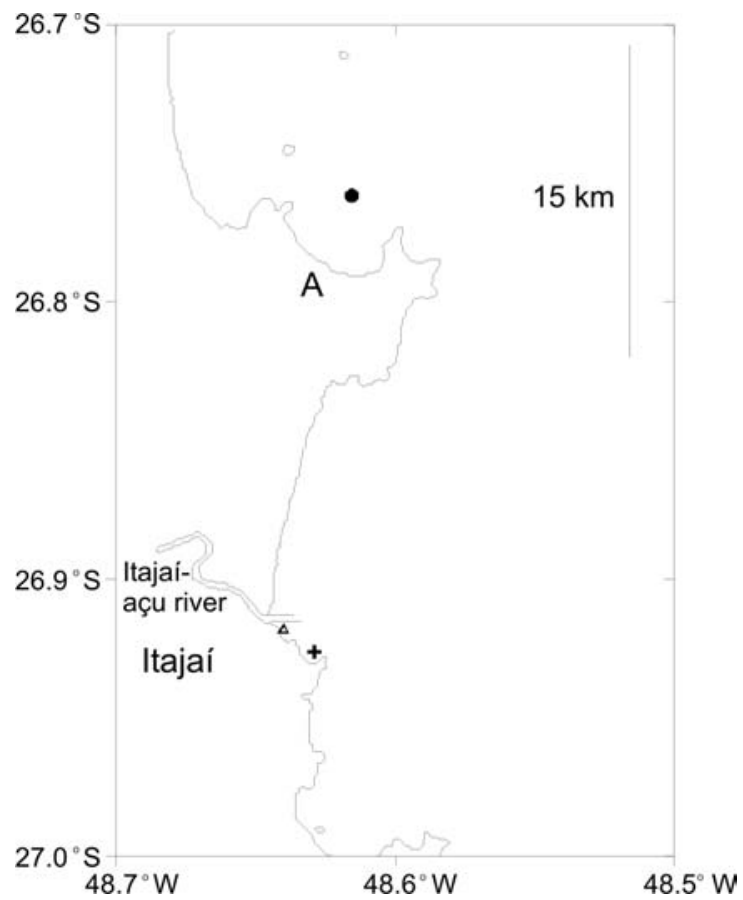

Fig. 1. Bloom sampling sites in Atalaia (triangle) and Cabeçudas (+) beaches, Itajaí - SC and the weekly monitoring site (circle) in Armação do Itapocoroy (A) are indicated. 


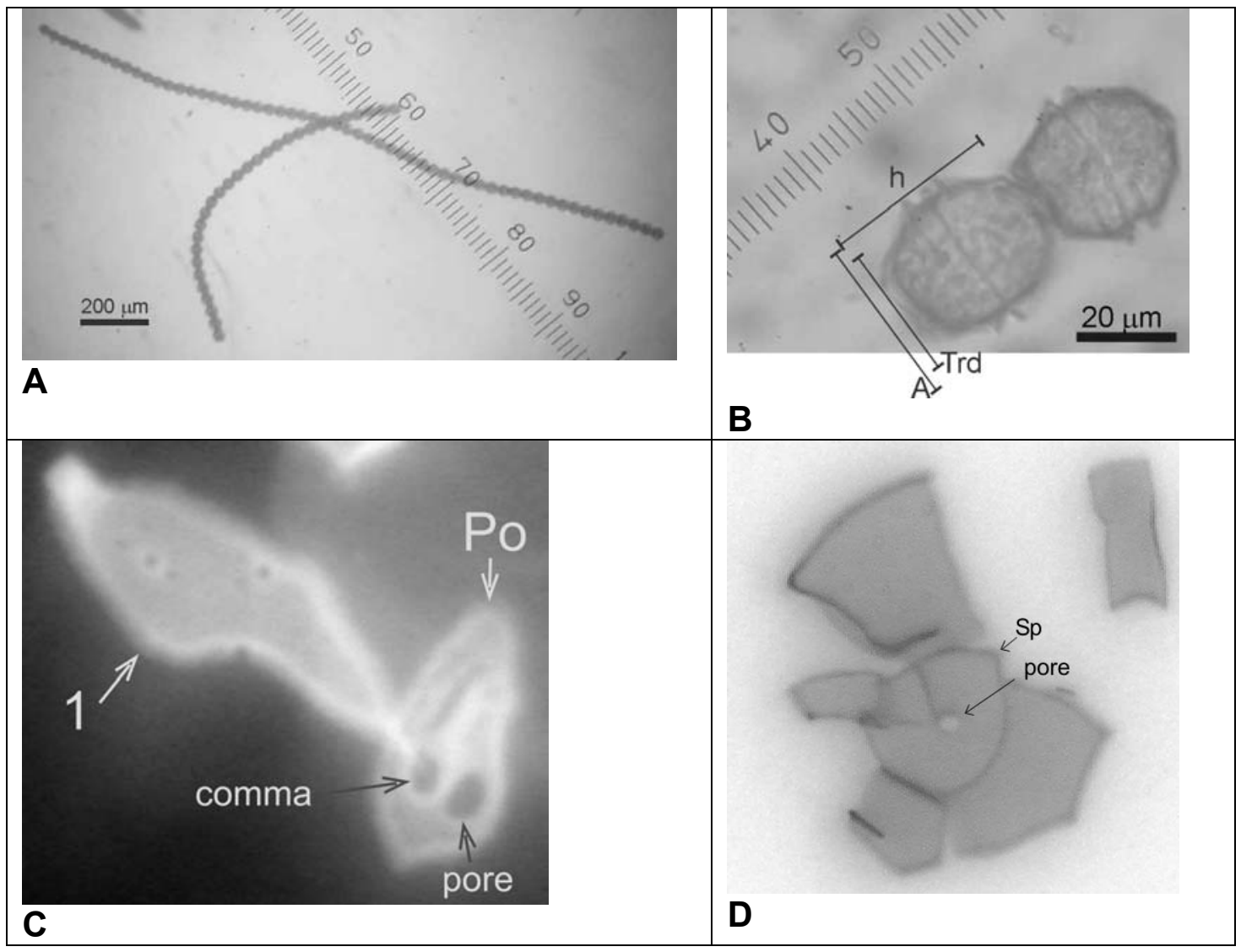

Fig. 2. A. fraterculus cells from the culture: a) in chains, b) cells in details (400x): A: width, Trd: transdiameter and h: height (Balech, 1995), c) apical pore complex (Po) with characteristic comma and pore, first apical plate (1) and d) posterior sulcal plate $(\mathrm{Sp})$ with pore, between other plates. Light microscope: $\mathrm{a}$ and $\mathrm{b}$. Epifluorescence: $\mathrm{c}$ and d.

The chlorophyll $a$ concentration $(\mathrm{Chl} a)$ was analysed by drowning around $80 \mathrm{~mL}$ of the water sample onto GF/F Whatman (bloom) or GF50-A Schleicher \& Schuell (WMP) glass fibre filters and extracting in $90 \%$ acetone for $24 \mathrm{~h}$ at $-18^{\circ} \mathrm{C}$. It was analysed in a Shimadzu LC 10 HPLC system fitted with a SPDM-10A diode array detector $(1 \mathrm{~nm}$ resolution) (Proença, 1997) and a $3.5 \mathrm{~cm}$ length Shimadzu Shim-pack FLC-ODS column. Chl $a$ in the Atalaia beach was the highest reaching $19.0 \mathrm{mg} \mathrm{m}^{-3}$ whilst in the Cabeçudas beach it was $4.6 \mathrm{mg} \mathrm{m}^{-3}$ (Fig. 3a). Chl $a$ from the WMP varied between 1.0 and 2.8 $\mathrm{mg} \mathrm{m}{ }^{-3}$ with the highest on August $26^{\text {th }}$ (Fig. 3a).

Around $300 \mathrm{~mL}$ of the blooms and WMP water samples were preserved in $2 \%$ Lugol and cells of $A$. fraterculus were counted in an inverted microscope Olympus IX50 following Utermöhl (1958) at a final magnification of $100 \mathrm{x}$ (Andersen \& Throndsen, 2003). Abundance of $A$. fraterculus was as high as 7.0 x $10^{5}$ cells $\mathrm{L}^{-1}$ and $8.8 \times 10^{4}$ cells $\mathrm{L}^{-1}$ for the Atalaia and Cabeçudas beaches, respectively (Fig. 3b). No cell of A. fraterculus was found in the sample from the WMP in August $12^{\text {th }}$, but they reached $7.0 \times 10^{3}$ cells $\mathrm{L}^{-1}$ a week later and to the maximum of $1.4 \times 10^{5}$ cells $\mathrm{L}^{-1}$ on August $26^{\text {th }}$, coincident with the highest $\mathrm{Chl} a$ concentration (Fig. 3). On the fifth week after the first detection, no cell of $A$. fraterculus was found in the sample of WMP (Fig. 3b). The difference between the Chl $a$ concentration and the cell counting for August $12^{\text {th }}$ and September $16^{\text {th }}$ was because Chl $a$ accounted for all the phytoplankton species present in the water sample while the cell counting was carried out for $A$. fraterculus only.

The cell size was determined at a final magnification of $400 \mathrm{x}$, measuring width (A), transdiameter (Trd) and height (h) (Fig. 2b) following Balech (1995). In general, the cells were wider than long, with variable size and smaller than those described in the literature (Table 1) as more elongated (Balech, 1995; MacKenzie et al., 2004). 

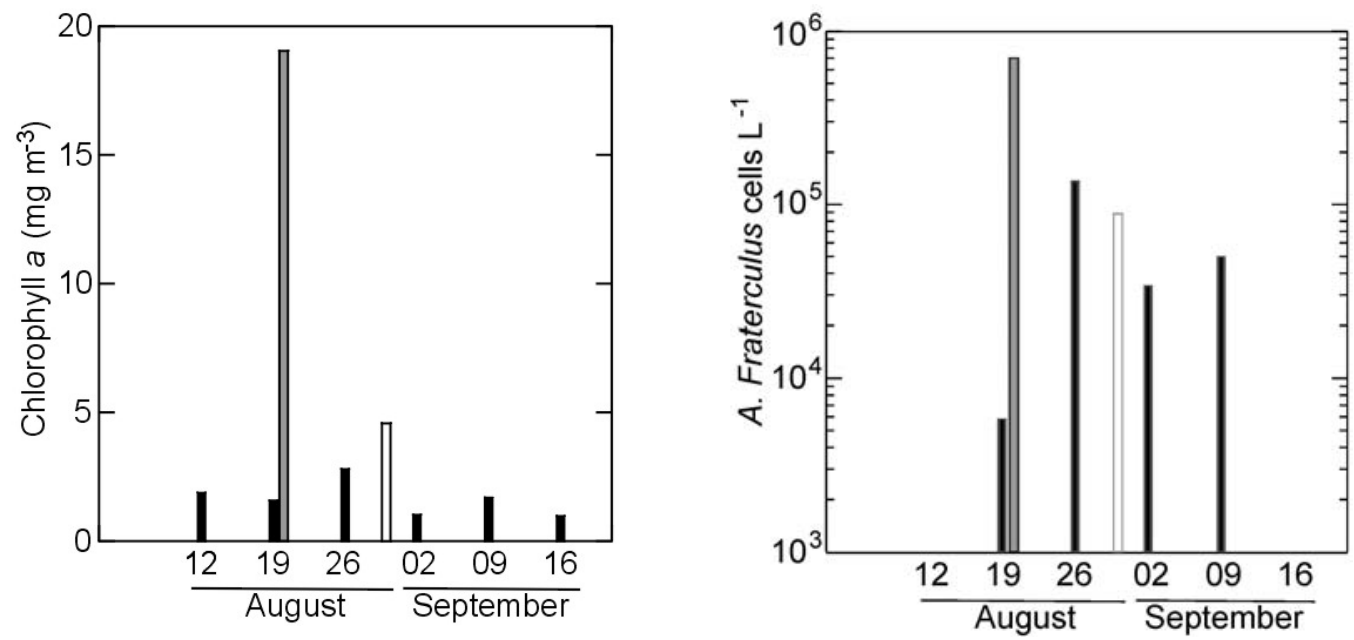

Fig. 3. a) Chl $a$ and b) cell counting of Alexandrium fraterculus for weekly monitoring programme (black) superimposed with samplings during the bloom events in the Atalaia (gray bar, August $20^{\text {th }}$ ) and Cabeçudas (open bar, August $30^{\text {th }}$ ) beaches. No cell of $A$. fraterculus was found on the August $12^{\text {th }}$ and September $16^{\text {th }} 2004$.

Table 1. Comparison of width (A), transdiameter (Trd) and height (h) of cells of Alexandrium fraterculus from different sources.

\begin{tabular}{cccl}
\hline \hline $\mathrm{A}(\mu \mathrm{m})$ & Trd $(\mu \mathrm{m})$ & $\mathrm{h}(\mu \mathrm{m})$ & Reference \\
\hline- & 28.0 to 43.0 & 28.0 to 43.0 & Fukuyo et al. $(1990)$ \\
29.0 to 47.0 & 26.0 to 37.5 & 32.0 to 49.5 & Balech (1995) \\
30.0 to 34.0 & - & 32.0 to 35.0 & MacKenzie et al. $(2004)$ \\
27.5 to 42.5 & 22.5 to 32.5 & 25.0 to 40.0 & Present work \\
\hline
\end{tabular}

Phycotoxin mice assays turned negative for paralytic shellfish poisoning (PSP) and diarrhetic shellfish poisoning (DSP) (Proença et al., 2002) for all the samples, confirming previous studies suggesting that A. fraterculus is not linked to PSP toxins (Noguchi et al., 1985; Proença et al., 2002; MacKenzie et al., 2004). Although non toxic, this species belongs to the toxic genus Alexandrium (Balech, 1995).

Filtered seawater samples frozen at $-18^{\circ} \mathrm{C}$ were analysed a month later for nitrate, nitrite, ammonium and phosphate (Strickland \& Parsons, 1972). Unfortunately samples collected for silica analysis were lost during the laboratory procedures. Nitrate, nitrite and phosphate (Fig. 4) reached their minimum value a week after the maximum cell concentration and then increased seven times (nitrate) or triplicated (nitrite) by September $16^{\text {th }}$, when no cell of $A$. fraterculus was found. Nitrate was the main nitrogen form corresponding to more than $60 \%$ of the total dissolved nitrogen (tDN), except on September $2^{\text {nd }}$, when ammonium accounted for about $94 \%$ of the tDN, but $A$. fraterculus was still densely present in the following week. Ammonium can become dominant when the system becomes anoxic, when algal cells die with subsequent release of ammonium or due to the bacterial activity (Spencer, 1975). Phosphate was always lower than $0.06 \mu \mathrm{M}$ with a slight decrease on September $2^{\text {nd }}$. No phosphate measurement was available for September $16^{\text {th }}$ when other nutrients presented maximum values (Fig. 4). The N:P ratio was always bigger (28:1) than the Redfield ratio of 16:1 (Redfield, 1963) with a peak of 93:1 on September $2^{\text {nd }}$. 
Although the interval between the samplings in the WMP was relatively large, i.e. one week, this pattern in the nutrients may be explained by the uptake of nitrate, nitrite and phosphate for the growth of the phytoplankton until the biomass maximum on August $26^{\text {th }}$; then the subsequent release of ammonium due to the start of the decay of the phytoplankton a week after and when no cell of $A$. fraterculus was detected, three weeks later, the nutrients were high again.

None of the water characteristics analysed (data not shown) could be correlated to the bloom concentrations. Only small changes in salinity (33.9 to 34.2 ) and depth of Secchi disk (2.5 and $3.2 \mathrm{~m}$ ) were detected during this period. The temperature increased from $19^{\circ} \mathrm{C}$ to $21^{\circ} \mathrm{C}$ between August $26^{\text {th }}$ and September $2^{\text {nd }}$. These values differ from those when A. fraterculus was found in low concentrations (between 20 and 705 cell L $^{-1}$ ) during the same WMP in 1997 (Rörig et al., 1998). At that time, water was warmer $\left(21\right.$ to $25^{\circ} \mathrm{C}$ ), saltier (33 to 37 ) and clearer (Secchi disk between 3.3 and $5.0 \mathrm{~m}$ ) (Rörig et al., 1998).

During August and early September 2004, when A. fraterculus was found in high concentrations, the wind was intense, blowing from N, NNE and SSW. In the morning of September $13^{\text {th }}$, the wind strengthened, its direction changed to ENE and this condition lasted for 36 hours. On September $16^{\text {th }}$, no cell of $A$. fraterculus was found. These changes in wind conditions may have contributed for the bloom to decay. Similar conditions were observed during the decay of a Mesodinium rubrum bloom in the same area in 2001 (Proença, 2004).

Although the bloom lasted for more than four weeks, the weekly sampling resolution during the WMP might not have covered in detail all of its dynamic behaviour. Additionally, other factors like grazing, bacterial activity and environmental factors of the water column should be assessed in a better time resolution if the purpose is to follow the development and decay of a bloom and its controlling factors.

The proximity in space and time between the samplings makes us believe that these three patches of A. fraterculus were part of one bigger bloom event, spanning for two to four weeks in an area covering at least $20 \mathrm{~km}$ along the coast of the cities of Itajaí and Penha.

The presence of toxic phytoplankton (Rörig et al., 1998; Proença et al., 2001; Schmitt \& Proença, 2000), cases of human intoxication (Zenebon \& Pregnolatto, 1992) probably due to mussel ingestion in SC (Proença et al., 1998a, b) and blooms, like the present one, might be a warning that the region may face an outbreak of harmful phytoplankton species in high concentrations which may result in financial losses and social harm for the region.

\section{ACKNOWLEDGEMENTS}

The authors would like to thank Sergey Araújo for the wind data measured at CTTMar / UNIVALI and to Valdenir Manoel Inês for his help during the bloom samplings. Comments from two anonymous reviewers led to substantial improvements to the manuscript. C.Y.O. was funded by the Brazilian Government under the CNPq contract 150028/2004-0.

\section{REFERENCES}

Andersen, P. \& Throndsen, J. 2003. Estimating cell numbers. In: Hallegraeff, G. M.; Anderson, D. M. \& Cembella, A. D. (eds). Manual on harmful marine microalgae. Unesco Publiching, Paris, p. 99-129.

Balech, E. 1995. The genus Alexandrium Halim (Dinoglagellata). Cork: Sherkin Island Marine Station.

Fukuyo, Y.; Takano, H.; Chihara, M. \& Matsuoka, K. 1990. Red tide organisms in Japan - an illustrated taxonomic guide. Tokyo: Uchida Rokakuho. 430p.

MacKenzie, L.; Salas, M.; Adamson, J. \& Beuzenberg, V. 2004. The dinoglagellate genus Alexandrium (Halim) in New Zealand coastal waters: comparative morphology, toxicity and molecular genetics. Harmful Algae. 3:71-92.

Noguchi, T.; Maruyama, J.; Ikeda, T.; Fukuyo, Y. \& Hashimoto, K. 1985. Protogonyaulax fractercula as a nontoxic plankton. Bull. Japan. Soc. Sci. Fish., 51(8):1373.

Proença, L. A. O. 1997. Separação de pigmentos fotossintéticos do fitoplâncton por meio de cromatografia líquida de alta eficiência (CLAE). Notas Téc. FACIMAR, 1:23-31.

Proença, L. A. O. 2004. A red water caused by Mesodinium rubrum on the coast of Santa Catarina, southern Brazil. Braz. J. Oceanogr., 52(2):153-161.

Proença, L. A. O.; Lagos, N.; Rörig, L. R.; Silva, M. \& Guimarães, S. 1999. Occurrence of paralytic shellfish poisoning - PSP in southern Brazilian waters. Ciência e Cultura, 51(1): 16-21.

Proença, L. A.; Rörig, L. R.; Barreiros, M. A. \& Lagos, N. 1998a. A possible case of diarrhetic shellfish poisoning in Santa Catarina, southern Brazil. In: Congresso LatinoAmericano de Ficologia, 4. Caxambú-MG. Anais 2:259263.

Proença, L. A. O.; Schmitt, F.; Costa, T. \& Rörig, L. R. 1998b. Just a diarrhea? Evidences of diarrhetic shellfish poisoning in Santa Catarina, Brazil. Ciência e Cultura, 50(6):458-462.

Proença, L. A. O.; Tamanaha, M. S. \& Souza, N. P. 2001. The toxic dinoflagellate Gymnodinium catenatum GRAHAM in Southern Brazilian waters: occurrence, pigments and toxins. Atlântica, 23:9-65.

Proença, L. A. O.; Tamanaha, M. S. \& Resgalla Jr., C. 2002. Toxicity of the aqueous extract of Alexandrium fraterculus Balech. In: International Conference on Harmful Algae, 10. St Petersburg, EUA.

Redfield, A. C.; Ketchum, B. H. \& Richards, F. A. 1963. The influence of organisms on the composition of sea water. In: Hill, M.N. (ed.) The Sea. New York: Interscience. v. 2:26-77. 
Rörig, L. R.; Guimarães, S. C. P.; Lugli, D. O.; Proença, L. A. O.; Manzoni, G. C. \& Marenzi, A. C. 1998. Monitorização de microalgas planctônicas potencialmente tóxicas na área de maricultura da enseada de Armação do Itapocoroy-Penha-SC. Notas Téc. FACIMAR, 2:71-79.

Schmitt, F. \& Proença, L. A. O. 2000. Ocorrência de dinoflagelados do gênero Dinophysis (Ehrenberg, 1839) na enseada de Cabeçudas (verão e outono de 1999). Notas Téc. FACIMAR, 4:49-59.

Spencer, C. P. 1975. The micronutrient elements. Riley, J. P. \& Skirrow, G. eds. Chemical Oceanography. London: Academic Press. 1087p.
Strickland, J. D. H. \& Parsons, T. R. 1972. A practical handbook of seawater analysis. $2^{\text {ed }}$. Ottawa: Fisheries Research Board of Canada.

Utermöhl, H. 1958. Zur vervollkomnung der quantitativen phytoplankton metodik. Mitt. Int. Ver. Limnol., 9:1-38.

Zenebon, O. \& Pregnolatto, N. P. 1992. Memórias técnicocientíficas da divisão de Bromatologia e Química. São Paulo: Instituto Adolfo Lutz: 100 anos do laboratório de Saúde Pública. Edição Comemorativa. p. 173-198.

(Manuscript received 04 November 2005; revised 23 June 2006; accepted 21 December 2006) 